\title{
Archaeological Monitoring of an Electrical Conduit Trench at Mission San Francisco de la Espada (41BX4), San Antonio, Bexar County, Texas
}

Barbara A. Meissner

Center for Archaeological Research

Follow this and additional works at: https://scholarworks.sfasu.edu/ita

Part of the American Material Culture Commons, Archaeological Anthropology Commons, Environmental Studies Commons, Other American Studies Commons, Other Arts and Humanities Commons, Other History of Art, Architecture, and Archaeology Commons, and the United States History Commons

Tell us how this article helped you.

This Article is brought to you for free and open access by the Center for Regional Heritage Research at SFA ScholarWorks. It has been accepted for inclusion in Index of Texas Archaeology: Open Access Gray Literature from the Lone Star State by an authorized editor of SFA ScholarWorks. For more information, please contact cdsscholarworks@sfasu.edu. 


\section{Archaeological Monitoring of an Electrical Conduit Trench at Mission San Francisco de la Espada (41BX4), San Antonio, Bexar County, Texas}

\section{Creative Commons License}

\section{(c) (1) \&}

This work is licensed under a Creative Commons Attribution-NonCommercial 4.0 International License 


\section{Archaeological Monitoring of an Electrical Conduit Trench at \\ Mission San Francisco de la Espada (41BX4), San Antonio, Bexar County, Texas}

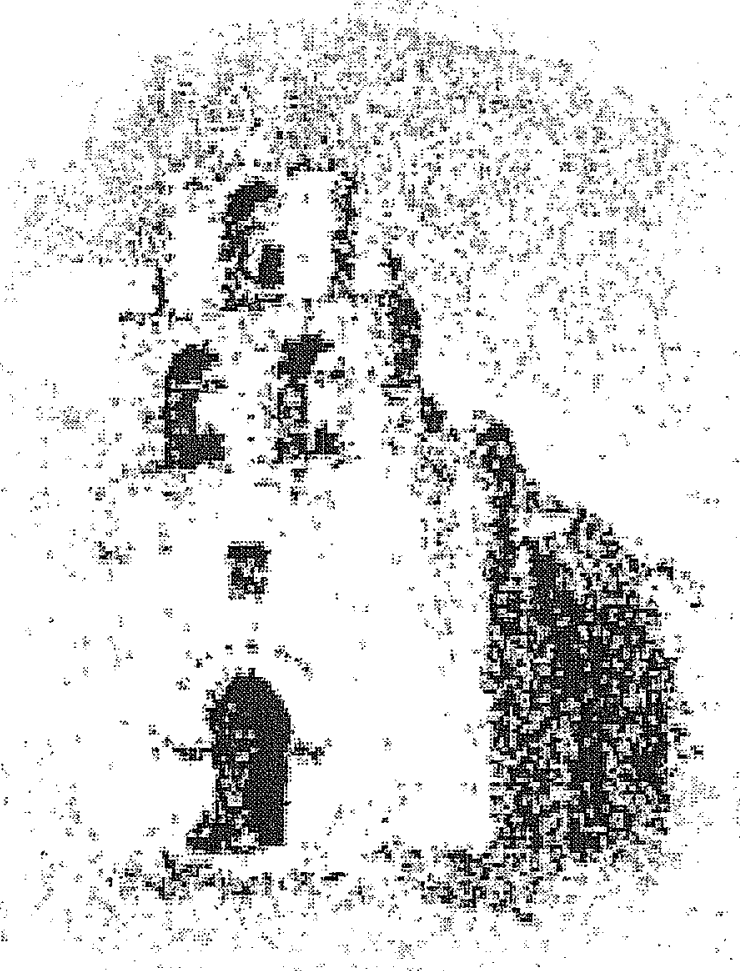

Barbara A. Meissner

Center for Archaeological Research The University of Texas at San Antonio Archaeological Survey Report, No. 288 1998

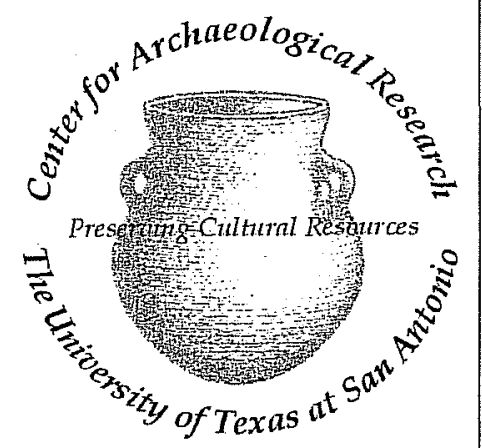





\title{
Archaeological Monitoring of an Electrical Conduit Trench at Mission San Francisco de la Espada (41BX4), San Antonio, Bexar County, Texas
}

\author{
Barbara A. Meissner
}

Robert J. Hard and C. Britt Bousman

Principal Investigators

Texas Antiquities Permit No. 1981

Ccopyright 1998

Center for Archaeological Research

The University of Texas at San Antonio

Archaeological Survey Report, No. 288 
The following information is provided in accordance with the General Rules of Practice and Procedure, Chapter 41.11 (Investigative Reports), Texas Antiquities Committee:

1. Type of investigation: Monitoring

2. Project name: Mission Espada Electrical Conduit Monitoring

3. County: Bexar

4. Principal investigators: Robert J. Hard and C. Britt Bousman

5. Name and location of sponsoring agency: Mission San Francisco de la Espada Parish, 10040 Espada Road, San Antonio, Texas 78214.

6. Texas Antiquities Permit No.: 1981

7. Published by the Center for Archaeological Research, The University of Texas at San Antonio, 6900 N. Loop 1604 W., San Antonio, Texas 78249-0658, 1998

A list of publications offered by the Center for Archaeological Research is available. Call (210) 458-4378; write to the Center for Archaeological Research, The University of Texas at San Antonio, 6900 N. Loop 1604 W., San Antonio, Texas 78249-0658; e-mail to car@lonestar.utsa.edu; or visit CAR's web site at http://www.csbs.utsa.edu/research/car/index.htm. 


\begin{abstract}
In April 1998, a hand-dug trench was excavated outside the parish offices of Mission San Francisco de la Espada to place below-ground electrical conduit. Due to the historic importance of the mission site, personnel from the Center for Archaeological Research of The University of Texas at San Antonio monitored the digging of this trench. The remains of a possible Colonial-period wall were uncovered outside the southern end of the building. Plans were made to run the electrical conduit above ground in that area, in order to avoid damaging the historic structure.
\end{abstract}




\section{Contents}

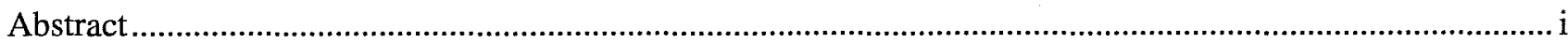

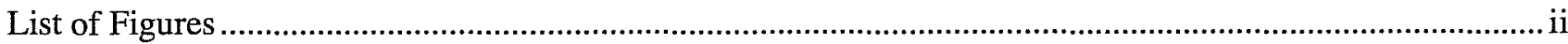

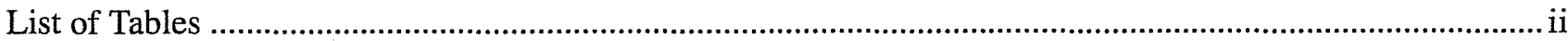

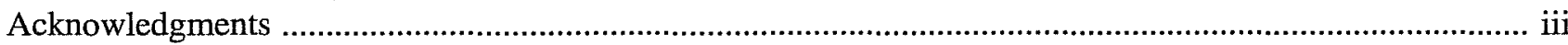

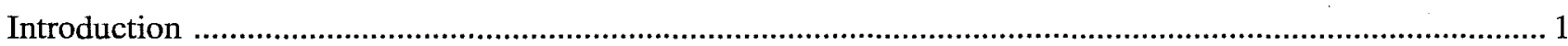

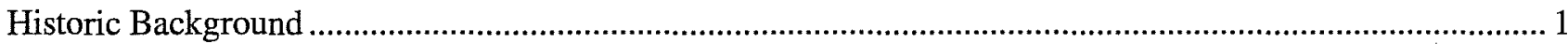

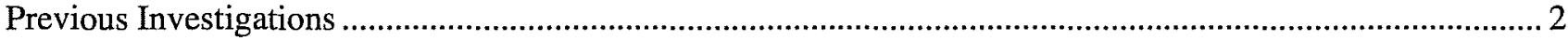

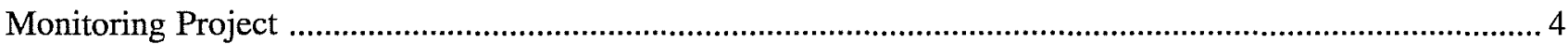

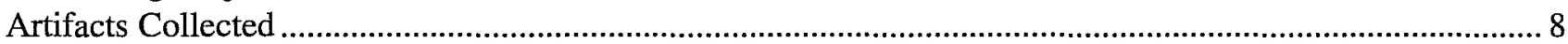

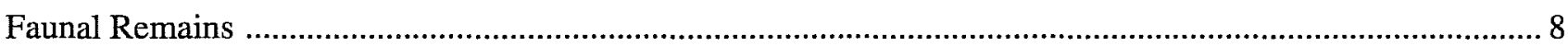

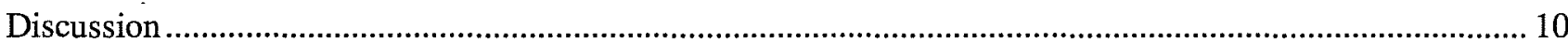

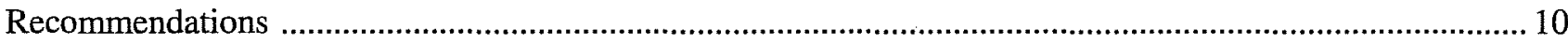

References Cited

\section{Figures}

1. The five missions of the upper San Antonio River valley. .......................................................... 1

2. Map of mission compound, showing areas of previous excavations................................................. 3

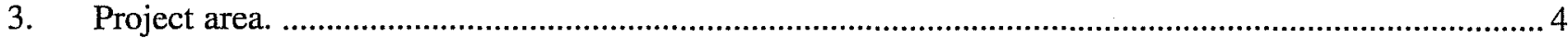

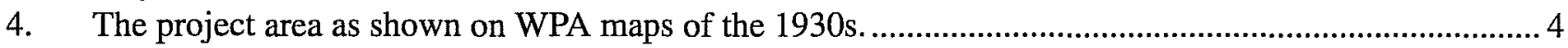

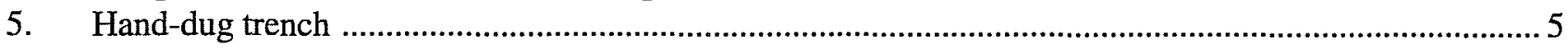

6. Remains of a Colonial-period stone wall found in trench. ..........................................................

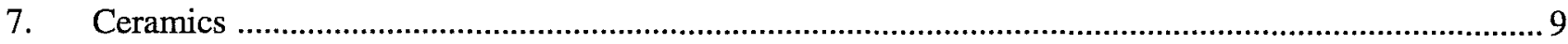

\section{Tables}

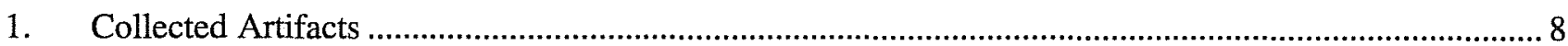




\section{Acknowledgments}

The Center for Archaeological Research (CAR) would like to thank Father Larry Janezic of San Francisco de la Espada Parish for his assistance with this project. The fieldwork was greatly facilitated by the cooperation of Clemente De Hoyos, electrical contractor, who made every effort to notify the CAR representative of his schedule and who made modifications to his original plans in order to avoid damage to historic structures. 



\section{Introduction}

Mission San Francisco de la Espada, the southernmost of the five missions in San Antonio, Texas (Figure 1), was founded in 1731. The chapel, which was constructed by 1745 , was damaged by fire on January 26,1998 . As part of a reconstruction project, a new electric line was to be run outside the western wall of the mission, adjacent to the parish offices, and inside the wall, along the southern end of the building. As the mission is an important historic site (41BX4), the Center for Archaeological Research (CAR) of The University of Texas at San Antonio contracted with the parish of San Francisco de la Espada to monitor the digging of an 18-inch-deep trench to accommodate the new conduit. This report describes the results of the monitoring project.

\section{Historic Background}

The following is a brief outline of the history of Mission Espada. The interested reader is referred to Habig (1968:192-233) for a general history. A detailed architectural history can be found in Ivey et al. (1990).

In 1690 Fray Damian Massenet founded the first mission in what is now Texas, in Nacogdoches County in East Texas. The mission was named San Francisco de los Tejas, for the Tejas group of Native Americans the missionaries hoped to convert to Christianity and Spanish citizenship (Habig 1968:192). This mission failed, due in part to an epidemic among the nearby native villages (Habig 1968:193-194). In 1716 a new expedition relocated the mission about 10 miles east of the original site, near the modern town of Alto. Five other missions were also founded in an effort not only to convert Native Americans but also to discourage the encroachment of the French from Louisiana (Habig 1968:196). The French drove the Spanish out of East Texas in 1719, but the latter returned in 1721 and changed the name of Mission San Francisco de los Tejas to San Francisco de los Neches. In 1731, however, the mission was moved to the San Antonio River Valley, and renamed San Francisco de la Espada.

The isolation of the mission made it a prime target of attack by hostile Native Americans in the region, and as a result the mission was built as a fortress, with chapel, missionaries' quarters, and rooms for the neophytes all enclosed in stone walls. The northwestern part of the mission was apparently constructed first. The chapel, which is still in use, was constructed by 1745 . Originally, it was intended to the be the sacristy of a much larger building, which was never constructed (Habig 1968:207; Ivey et al. 1990:140). Fray Ortiz's report in 1745 indicated that there were 204 Native Americans living at the mission (Habig 1968:211). Corn, beans, melons, pumpkins, and cotton were grown. The mission had about 1,150 head of cattle, sheep, goats, and horses, and 16 pair of oxen (Habig 1968:210). Individuals from 25 different named groups are recorded in the birth, marriage, and death records of Espada mission (Campbell and Campbell 1985:67). In 1773 the mission was

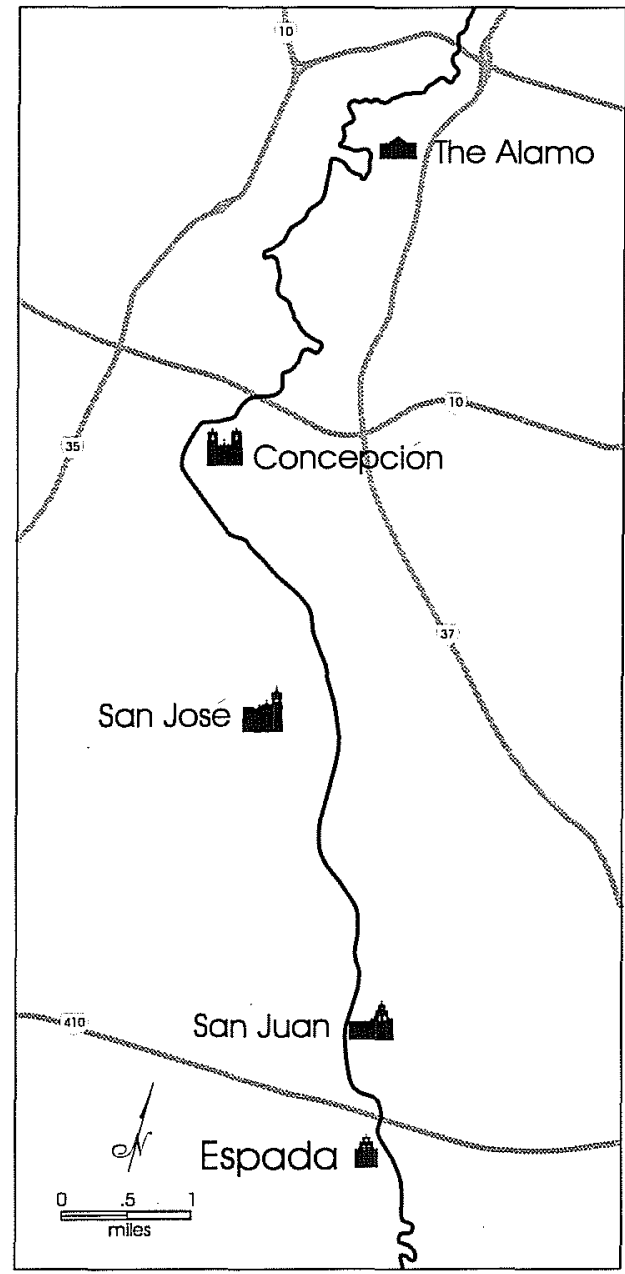

Figure 1. The five missions of the upper San Antonio River valley. Mission Espada is the southermmost of the missions. 
transferred from the control of the College of Querétaro to the College of Zacatecas (Habig 1968:215). In the 1780s additional construction added the southeastern plaza and a bastion, with places for three cannon and seven musket ports in the southeastern corner (Meskill 1992).

By 1789 only 57 Native Americans lived at the mission. In 1793 the decree of partial secularization was carried out. The mission lands were surveyed and the 15 heads of families still living at the missions were each given tracts of land. Final secularization was complete in 1824 (Habig 1968:218-219, 224).

Spanish soldiers were stationed at the mission in the 1820s. Before 1835, mission buildings had become the property of two owners, José Dolores Casanova and Salvador Diaz.

The mission was used as a temporary fortress by James Bowie and James W. Fannin, Jr., in the early days of the Texas rebellion in the fall of 1835 (Habig 1968:225). The mission was able to withstand attack by about 200 Mexican soldiers, but was later abandoned in favor of the northernmost of the missions, San Antonio de Valero (the Alamo), which Bowie felt was more defensible. At the end of the war Espada was left largely in ruins (Habig 1968:225).

In 1858 Father Francis Bouchu began a lifelong interest in Mission Espada, even establishing a residence in the ruins. It was Father Bouchu who restored the chapel to a usable condition (Habig 1968:228). During his tenure as rector of Espada church, Father Bouchu apparently purchased the land containing the mission and was responsible for most of the reconstruction carried there. Upon his death, the property was passed to his niece, an Incarnate Word sister. After her death in 1912, it became the property of the Incarnate Word congregation. Works Progress Administration (WPA) reconstruction of this mission was limited to mapping walls and tracing some of the wall remnants (Smith 1980). In 1981 the title to the mission was passed to the National Park Service (NPS).

\section{Previous Excavations}

The archaeological record for Mission Espada is relatively meager. Since the work done by the WPA in the 1930s, only six projects have been carried out in and near the mission. Project areas are shown in Figure 2.

In 1976 Fox and Hester (1976) excavated a test pit inside and a series of test pits around the exterior wall of the bastion as part of a project to stabilize and repair the tower. Evidence was found to suggest that the bastion was originally built as a separate structure, and the compound wall added latter (Fox and Hester 1976).

In 1977 the Texas Historical Commission excavated two lime kilns just north of the mission compound (Killen and Scurlock 1977). In 1981 Fox (1981) excavated north of a wall which had tentatively been identified as a cemetery wall by Smith. A thin layer of artifacts was recovered, but no evidence of a cemetery was found.

In 1984 the NPS investigated the rooms at the southeastern corner of the compound prior to their stabilization (Escobedo 1984). The room west of the bastion was found to have a well-made sandstone floor under some fill. Escobedo (1984) believed that this might have been the threshing floor mentioned in the 1772 inventory.

In 1990 Meskill (1992) excavated three test units along the east and south walls of the compound to examine the Colonial-period foundations and to determine the depth of fill overlying Colonial and nineteenth-century deposits in that area. She found that twentiethcentury construction had destroyed most of the foundation in the test pit on the east wall, but Colonial foundations were still extant in the test pits on the south wall. Remains of a wall were found in the third unit, placed in the courtyard (Meskill 1992: 35-36).

In 1996 a series of 26 shovel tests was excavated in a 50 - $\mathrm{ft}$ grid pattern in the eastern portion of the compound, in the area known as the New Plaza (Gross 1997). This project was necessitated by the plan of a 


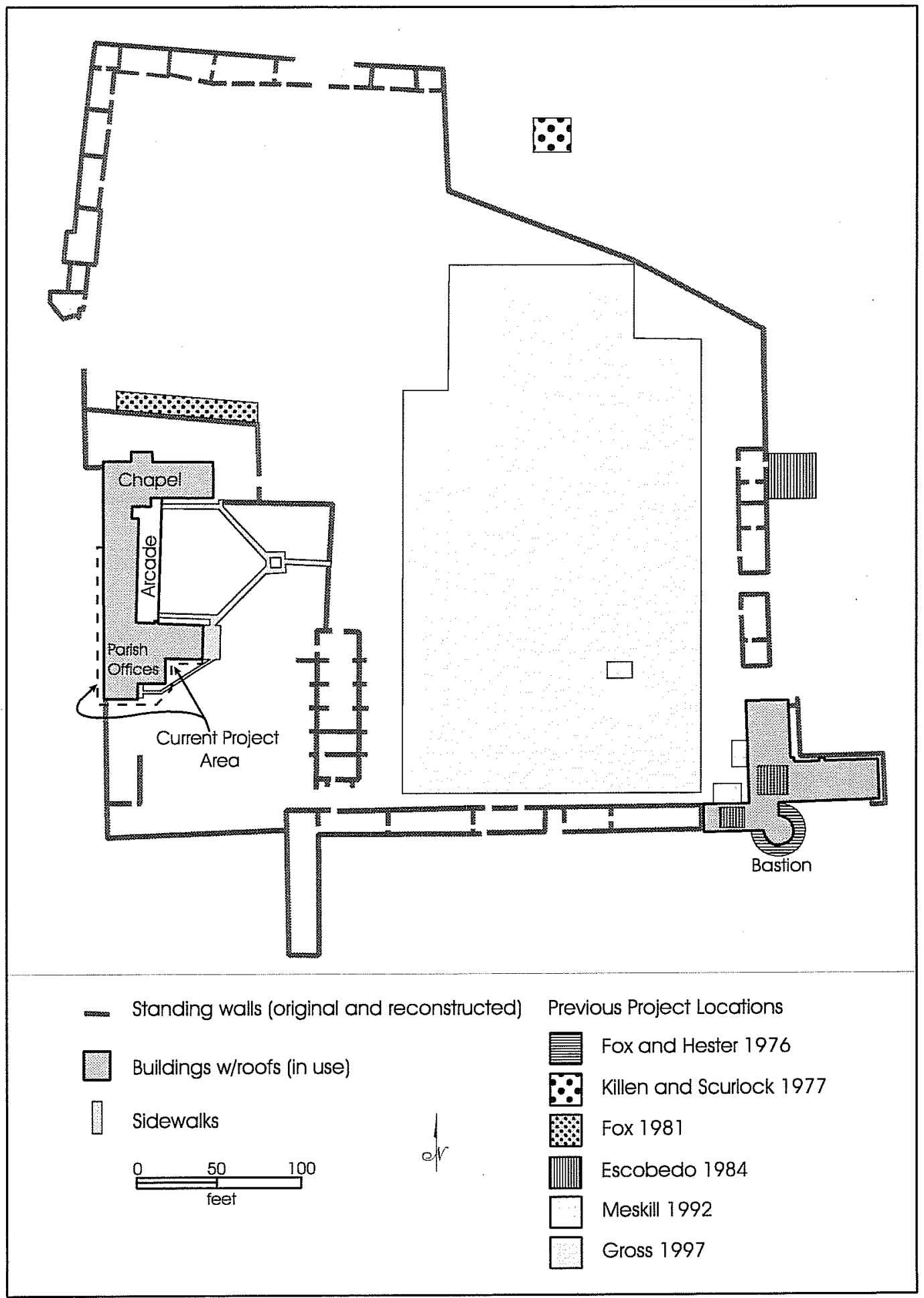

Figure 2. Map of the mission compound, showing areas of previous excavations, and current project.

movie company to build a set in the compound that would require pounding eight-inch stakes six inches into the ground (Gross 1997:1). Colonial-period artifacts were found in much larger numbers in the northern half of the project area, while post-Colonial ceramics and other artifacts were found mostly in the southern half (Gross 1997:6). 


\section{Monitoring Project}

Prior to the beginning of the project, maps of the proposed excavation area (Figure 3 ) were compared with maps made by Smith in the 1930s which showed all the wall remains that had been uncovered by the WPA testing (Figure 4). These maps showed that the southernmost section of the building, along which the pipe trench was to be dug, had not been built as of the early 1930s. It appeared that the south wall of the newer portion of the building had been constructed

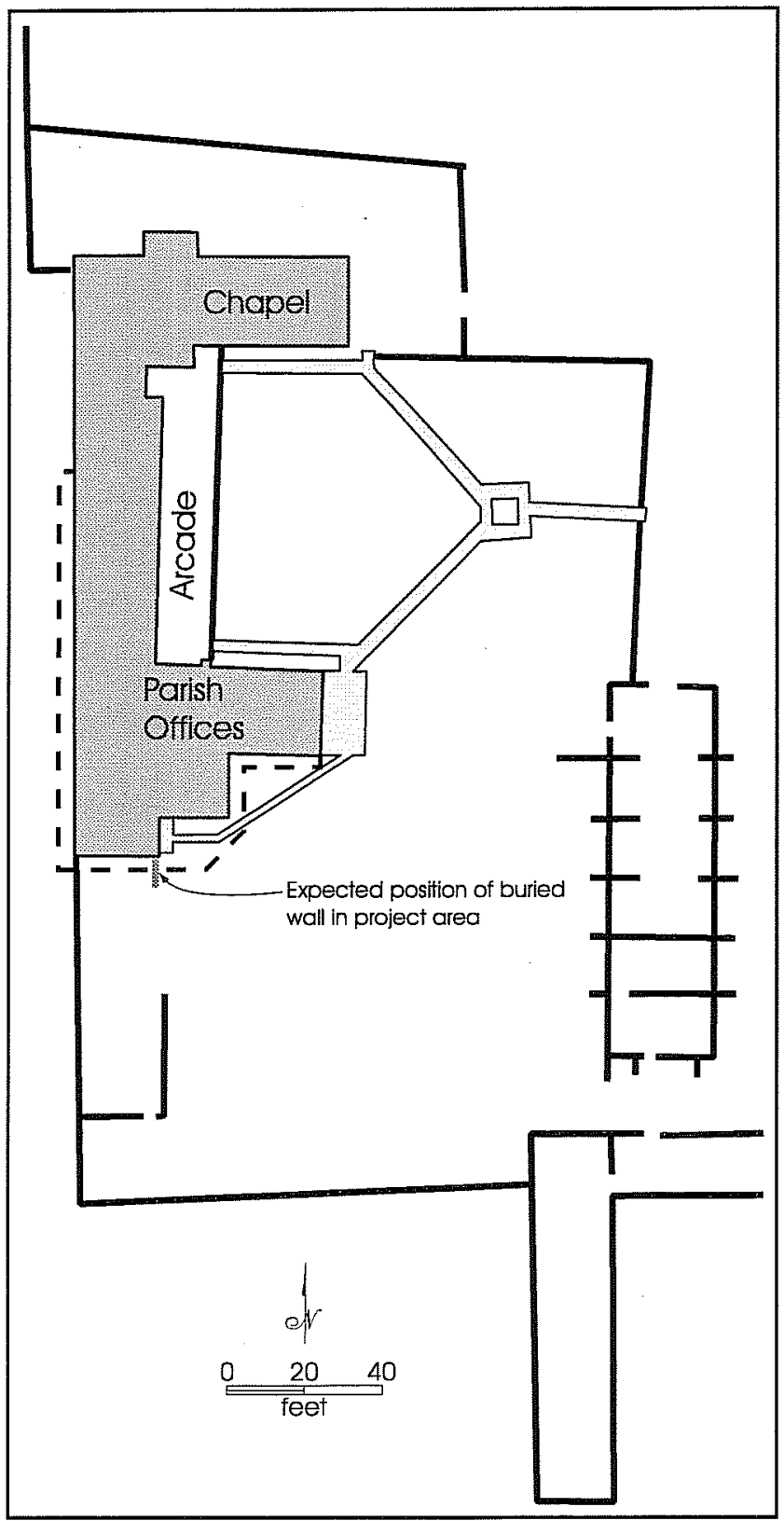

Figure 3. Project area. on the northernmost remains of the foundation just south of the building labeled "Old School" in Figure 4. It was thus possible that the planned trench would encounter portions of the wall running south (see notation in Figure 3). This was the only place where maps showed a likelihood of disturbance of historic structures.

On April 1, 1998, digging of the trench began, starting at the eastern end, inside the wall (Figure 5). The project was completed on April 7. A staff archaeologist

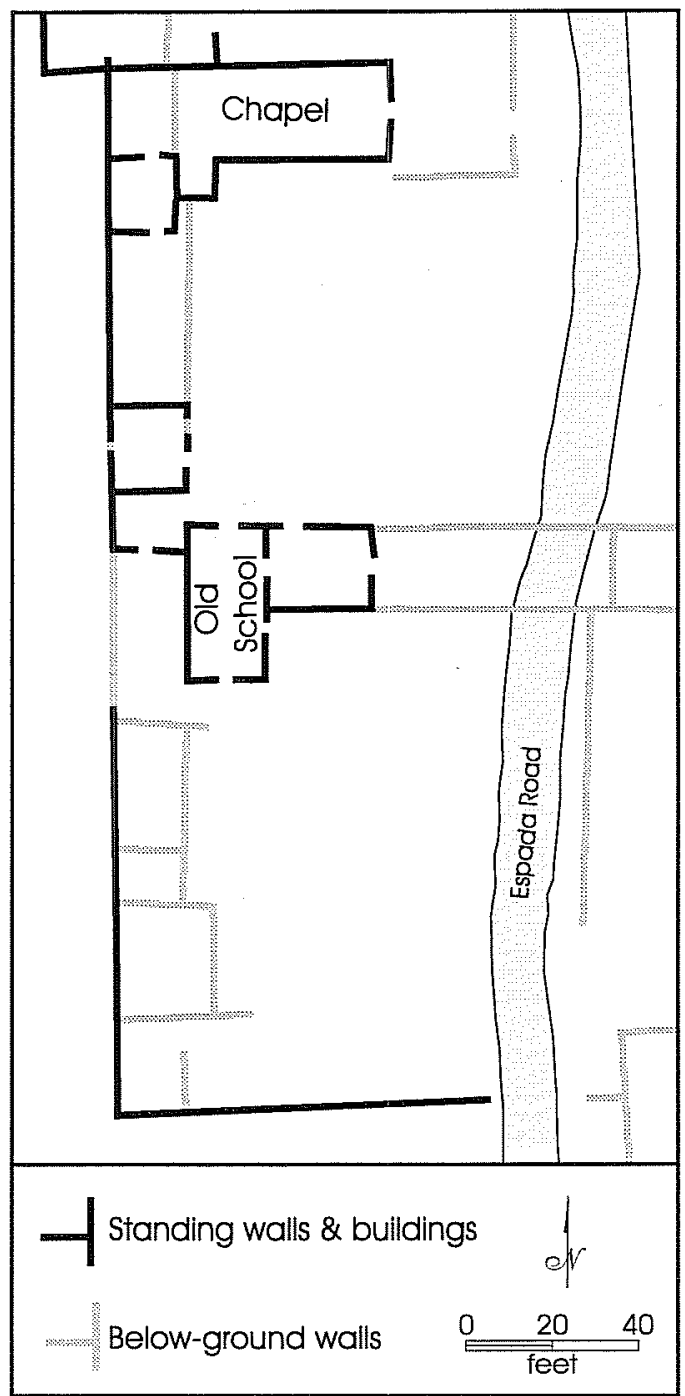

Figure 4. The project area as shown on WPA maps of the 1930s, showing numerous stone walls south of the project area. Note numerous changes in buildings as shown in Figure 3. Based on WPA map ca. 1933. 


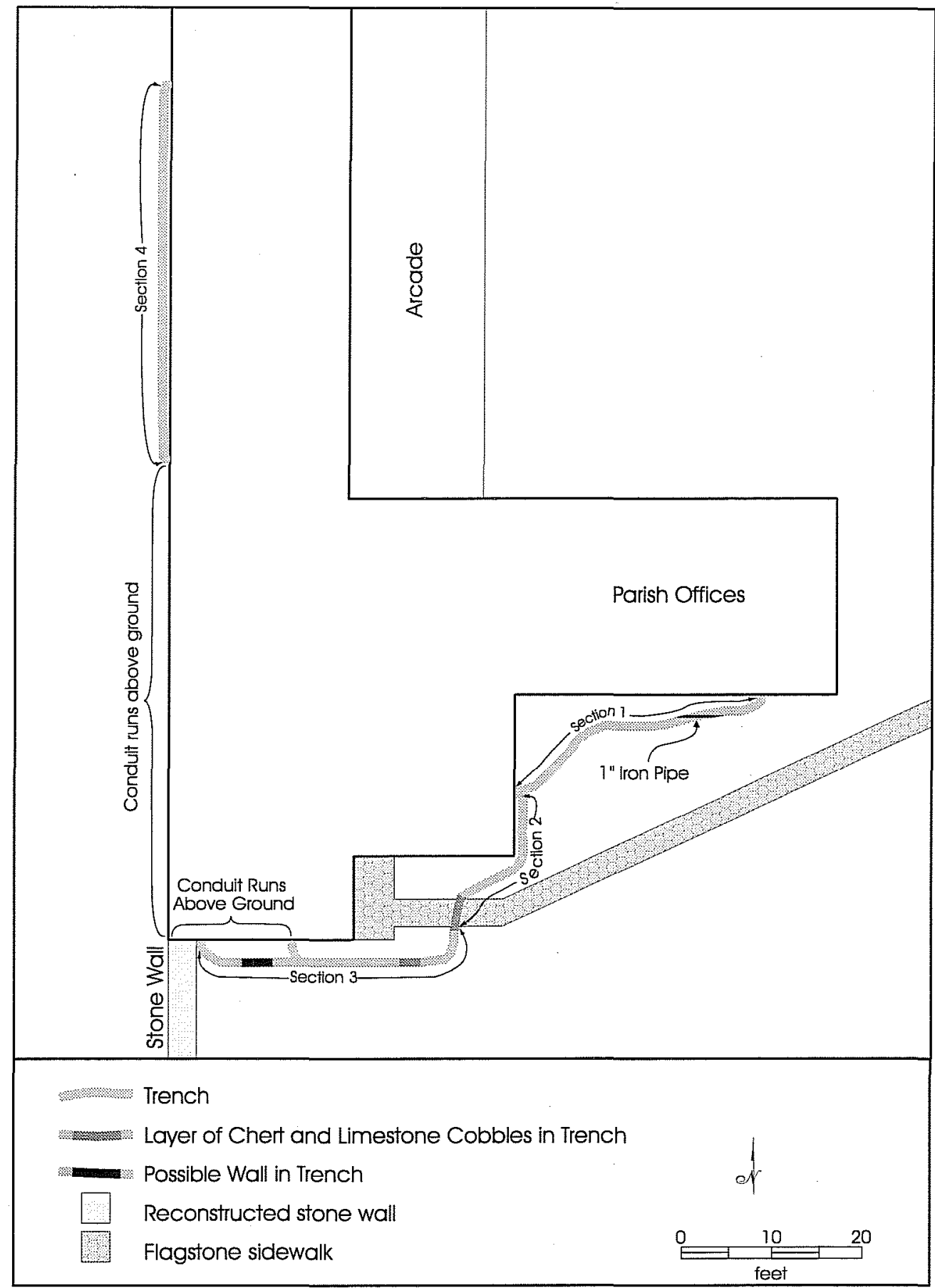

Figure 5. Hand-dug trench

from CAR observed the operation while a worker hand-dug a trench approximately 10 inches wide and 18 inches deep. Artifacts were collected if they were temporally diagnostic, and a sample of non-timediagnostic artifacts such as bone was also recovered (see artifact descriptions below). The trench was divided into sections in order to facilitate description (see Figure 5).

The sediments in the first part of Section 1 were found to be a dark gray-brown sandy loam with very few artifacts, almost all of which were late twentieth 
century in origin. The profile of the trench, though only 18 inches deep, often showed several layers of slightly different colors, suggesting the sediments were, for the most part, fill. At about 3 feet along the trench

1 -inch cast iron pipe was uncovered, running parallel to the wall (see Figure 5). Sediments after the pipe and continuing to the end of Section 1 were a more compact, darker gray-brown sandy clay loam with occasional lenses of lighter gray sediments mixed with quantities of caliche. An occasional large, flat sandstone rock was encountered, but each was found to be a single stone. There were a few more artifacts in this part of Section 1, including part of a grill from an iron stove, and one piece of handpainted whiteware.

The first part of Section 2, along the east side of the building, had a lens of dense white caliche about four inches below the ground surface and about 4-10 inches deep. The sediments below this caliche layer appeared undisturbed, while those above it appeared to be fill. Only a few pieces of glass, unidentifiable metal fragments, a few pieces of bone, and one piece of Goliadware were found in Section 2. The bone and the Goliadware appeared to have come from below the caliche layer. About six inches from the flagstone sidewalk (see Figure 5) and about six inches below ground surface was a layer of rounded chert cobbles, along with a few limestone cobbles. They were fistsized to somewhat larger in size and formed a solid layer, apparently deliberately laid, one stone deep, in a light-colored, sandy clay matrix. This layer of cobbles continued beneath the flagstone sidewalk to a point about six feet on the other side. A four-inch layer of builder's sand lay directly beneath the flagstones, on top of the cobble layer.

The sediments in the first part of Section 3 of the trench appeared to be similar to the lower part of the sediments in Section 2, that is, dark gray-brown sandy clay with a few lenses mixed with caliche. Only the upper six inches of the trench in this section appeared to be fill. In several places along the first part of Section 3 were large animal bones (see faunal section). There was a second layer of chert and limestone cobbles about two feet wide some five feet beyond the flagstone sidewalk (see Figure 5). This layer appeared to be exactly like the layer found under the flagstone sidewalk, although there was no builder's sand above it. From about this point on numerous large rocks were found in the trench. All rocks were examined to determine if they were single rocks or more than one layer thick. Special attention was paid to the section of trench which was expected to encounter the remains of a buried stone Colonial-period wall (see Figures 3 and 4). However, there was no sign of this wall in the trench.

The wall remnant presented a problem for the contractor, as the zoning laws required the electrical conduit to be 18 inches below grade. A compromise was developed. Since plans already called for the conduit to be run above ground over the reconstructed mission wall, the contractor decided to continue the conduit above ground, attached to the southern wall of the building, to a point where there was an existing conduit and junction box (Figure 6). This made it possible to back fill the trench over the wall remnant without disturbing it. This solution was approved by the Texas Historical Commission. A new section was excavated to the junction box (see Figure 6).

The remains of a stone wall were found about eight feet east of the reconstructed stone wall running south from the southern end of the building, (Figure 6). The top of the wall was between 7 and 15 inches below ground surface. The wall consisted of rough sandstone and limestone pieces, of sizes ranging from 8 to 20 inches across, laid without mortar. There were at least three layers of stone, although the bottom of the wall was not excavated.

Section 4 of the trench ran along the western side of the building, outside the compound (Figure 5). The trench was dug from one electrical junction box to another, about $42 \mathrm{ft}$ long. The contractor planned to use an extant, above-ground section of electrical conduit from the end of Section 4 to the corner of the building. The sediments in Section 4 were a very soft, friable sandy loam which was almost completely 


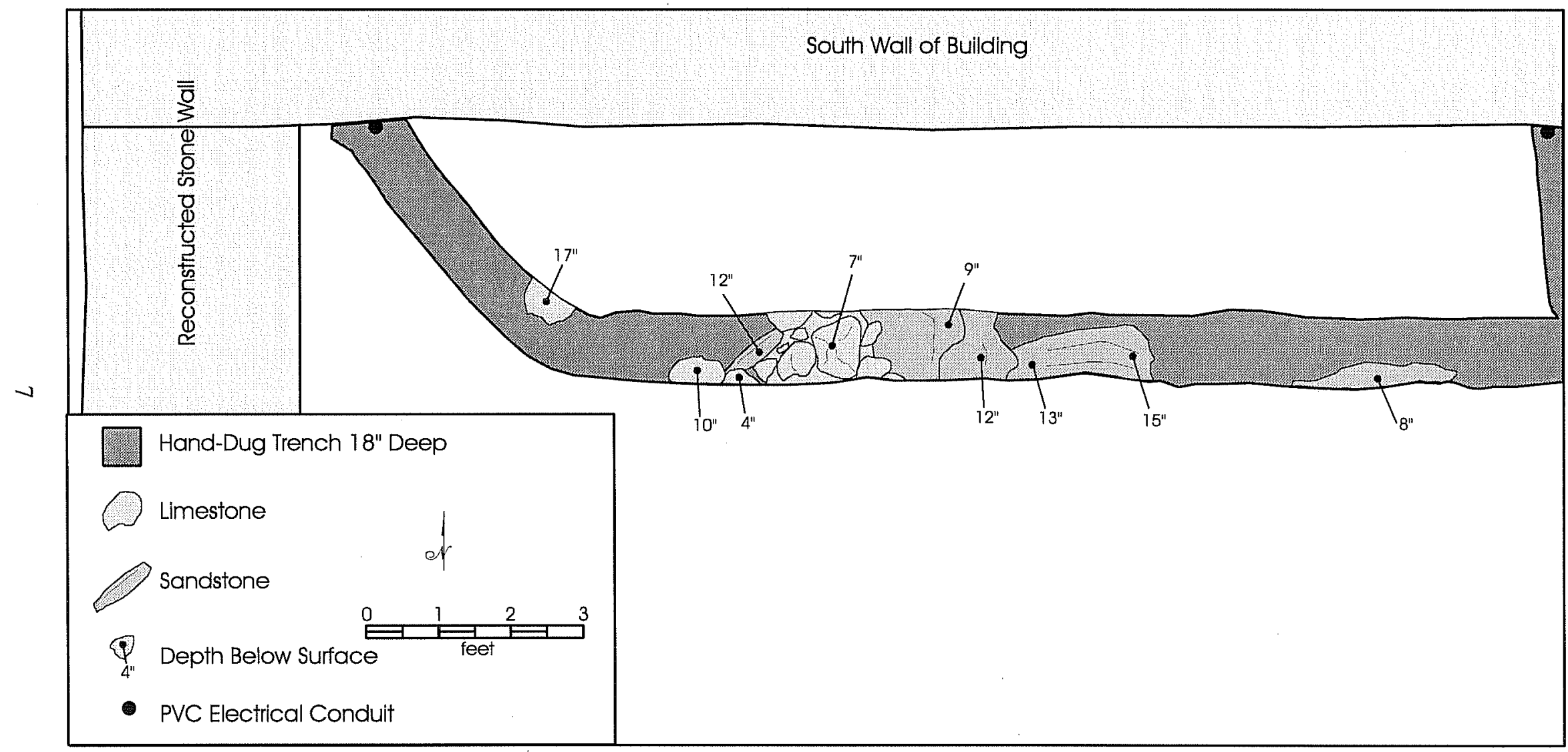

Figure 6. Remains of a Colonial-period stone wall found in trench. 
sterile. Only a few pieces of brick and glass, and one large lead-glazed pot fragment, were observed. The latter was collected along with one glass bottle fragment and the only bone found in this section of the trench. The wall was left in place and covered with sediment. The electrical connedtion was strung above ground

\section{Artifacts Collected}

Only temporally diagnostic artifacts from the trench were systematically collected. Table 1 lists artifacts by category and by trench section. More-detailed descriptions follow.

Four of the nine ceramic sherds collected are from the Colonial period. One is a piece of Goliadware, recovered from below the caliche lens in Section 2. Goliadware is an undecorated brownware commonly found in Spanish colonial sites in South Texas (Hard et al. 1995:41). It is probably a continuation of the prehistoric Leon Plain brownware found in many Late Prehistoric sites in the area (Fox et al. 1976:67). Goliadwares have a coarse-grained, tan to reddishbrown, bone-tempered paste, usually with a band of dark color at the center reflecting incomplete firing (Hard et al. 1995:41). This sherd had been heavily smoke-stained both inside and out.

Three pieces of sandy-paste lead-glazed ceramics were also recovered. Two of these are the bottoms of large bowls or pots, finished with a thin lead glaze on the interior only. One of these, found in Section 3, has the remains of a design in dark green glaze at the bottom

Table 1. Collected Artifacts

\begin{tabular}{|c|c|c|c|c|c|c|}
\hline \multirow[b]{2}{*}{$\begin{array}{l}\text { Trench } \\
\text { Section }\end{array}$} & \multicolumn{6}{|c|}{ Artifact Category } \\
\hline & 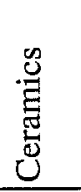 & $\begin{array}{l}\frac{n}{0} \\
\frac{0}{0} \\
0\end{array}$ & 总 & 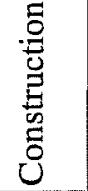 & 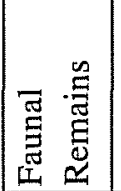 & $\frac{\vec{\pi}}{0}$ \\
\hline 1 & 2 & 1 & & 3 & 5 & 11 \\
\hline 2 & 1 & 1 & & & 34 & 36 \\
\hline 3 & 5 & 2 & 1 & 1 & 20 & 29 \\
\hline 4 & 1 & 1 & & & 1 & 3 \\
\hline Total & 9 & 5 & 1 & 4 & 60 & 79 \\
\hline
\end{tabular}

of the bowl, and a hand-applied foot ring (Figure 7a). The other, found in Section 4, has a plain, flat base. The third piece, found in Section 3, is a body sherd with shallow striations on the interior, smoke stains on the exterior, and a band of dark color in the paste, indicating that it was incompletely fired (Figure 7b). Sandy-paste lead-glazed wares were imported to Texas from the interior of Mexico during the Colonial period, and are often found in quantity in sites from that period (Dial 1992:33).

Two tiny fragments of unglazed ceramics were also recovered. One, from Section 1, has a course, sandy texture. The other, from Section 3, has a much finer texture. Both are too small to identify further.

The other ceramics recovered were all refined whitewares. Two of these, from Section 3, are undecorated. One is the rim sherd of a steep-walled cup. The other is a small body sherd. Two sherds of decorated whitewares were recovered, one of which is a sherd of handpainted ware, from Section 1 (Figure 7c). Handpainted wares were popular in the early nineteenth century in Texas (Dial 1992:41). The other sherd has cut sponge decorations in red and green (Figure 7d). Cut sponge decorations on whiteware were most popular between about 1830 and 1870 (Dial 1992:44).

Five pieces of glass were collected, of which only one, the bottom of a Log Cabin Syrup bottle, could be identified. It was recovered from Section 1.

A small pink and white plastic toy telephone receiver was collected from Section 3. This toy is made of modern plastics. Its shape suggests it was made at some time between the late 1960 s and the 1980s.

A piece of metal grill was recovered from near the end of Section 1. It cannot be identified with certainty, but is similar to grills often seen on gas heaters. One set of ceramic electric insulators with a nail through them was also recovered from Section 1. A light bulb base insulated with hard rubber, of the sort in common use in houses in the early twentieth century, was also recovered from Section 1. One large cut nail was recovered from Section 3. 


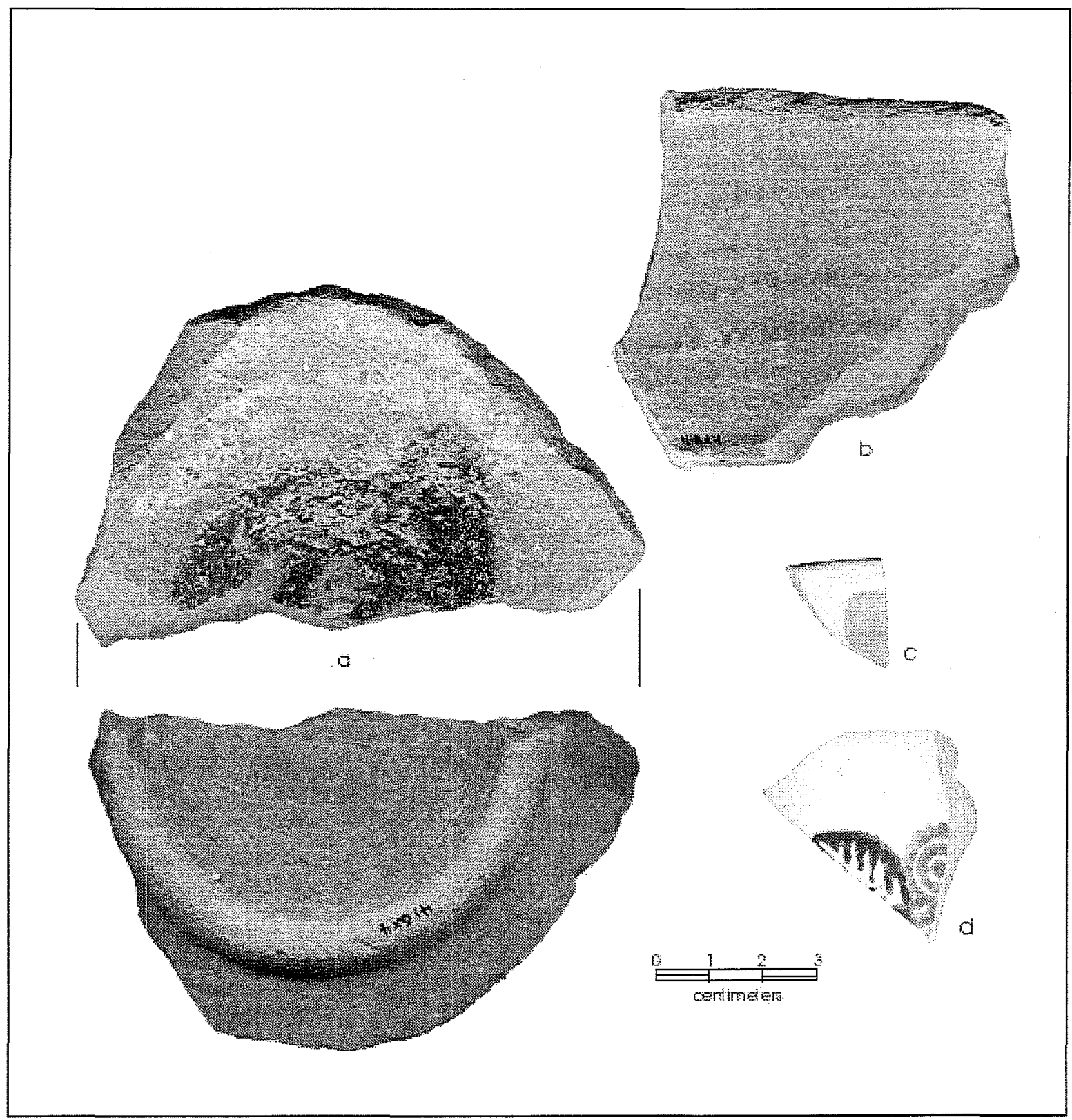

Figure 7. Ceramics. a. base of a bowl with green pattern in bottom and foot ring; b. body sherd with striations; c. handpainted whiteware; d. cut sponge-decorated whiteware.

\section{Faunal Remains}

Not all animal bone observed during the digging was collected. Although bone collection was not systematic, approximately half the bone observed was collected in each trench section.

Table 1 shows the largest bone counts were in Sections 2 and 3. This is somewhat misleading, however, as most of the bone collected from Section 2 was from a single highly fragmented mandible of either Capra (domestic goat) or Ovis (Domestic sheep). Most of the bone in large pieces was found in Section 3, in two areas: under the flagstone sidewalk (and under the cobble layer); and in an area roughly between the second layer of cobbles and a line running south from the building wall (see Figure 5). This bone was in large pieces, some of which displayed damage characteristic of breakage while the bone was fresh.

A formal analysis of the bone was not done. A first 9 phalange and accessory carpal of the species Bos taurus (cattle) was the only bone identified to species 
level; however most of the bone was from animals of the cow/horse size range.

\section{Discussion}

There has been little excavation at Mission Espada, thus little is known about the location and condition of Colonial and nineteenth-century deposits. Maps of the site in the 1930s, when subterranean wall remains were being exposed, show the extension which now forms the southernmost wing of the building was built on top of the northernmost wall of a series of rooms that once stood inside the west wall (see Figure 4). The only wall remnant considered likely to be encountered by the current project was the eastern wall of that room; however, no signs of that wall were found. Instead a wall remnant was discovered in an unexpected location, about eight feet inside the outer wall. The origin of this wall is unknown, and without more excavation it cannot be properly assessed.

The limited view afforded by a trench only 18 inches deep make statements about the origin and degree of disturbance of sediments difficult. However, those sediments uncovered by the excavation appeared to be largely fill and/or highly disturbed, although in the southern part of Section 2 and most of Section 3 they appeared relatively undisturbed.

The possibility that undisturbed Colonial-period deposits are present in the project area is also suggested by the discovery of Goliadware and leadglazed ceramics. The large size of the latter is especially suggestive of relatively undisturbed context.

The areas with large amounts of bone in good condition and in fairly large pieces also suggests the presence of an undisturbed Colonial deposit. Hard et al. (1995:74) and Gross (1997:11) found that faunal remains tend to be closely associated with Colonial- period ceramics at mission sites in San Antonio, and feel that most bone in mission sites is Colonial in origin (Hard et al. 1995:94).

This small monitoring project has emphasized the problems associated with planning any kind of construction that disturbs the ground at the missions, especially Mission Espada, which is not welldocumented archaeologically. Although the information available before the project indicated that there could be a wall in one location, there was, in fact the remains of a wall in another location entirely. In addition, some evidence of the presence of a Colonial-period deposit, which may be relatively undisturbed, was also uncovered.

\section{Recommendations}

We recommend that any further work in the area of Sections 2 and 3 of the trench be carefully monitored by archaeologists. The presence of quantities of large bone and large pieces of Colonial-period ceramics suggests there may be undisturbed Colonial deposits in the area.

The presence of the previously undocumented wall indicates that the architectural history of Mission Espada is not complete. Care must always be taken to avoid disturbing walls and other structures, as well as cultural deposits, whenever plans call for disturbance of the ground surface.

The project also provided an excellent example of how the contractor, the Texas Historical Commission, and CAR can work together to solve problems. This kind of cooperation allows needed work to be accomplished in a timely and cost-effective manner while preserving the important cultural resources at the missions. 


\section{References Cited}

Campbell, T. N., and T. J. Campbell

1985 Indian Groups Associated with Spanish Missions of the San Antonio Missions National Historical Park. Special Report, No. 16. Center for Archaeological Research, The University of Texas at San Antonio.

Dial, S. W.

1992 Ceramics. In Archaeological Investigations in Alamo Plaza, San Antonio, Bexar County, Texas, 1988 and 1989, by A. A. Fox, pp. 29-46. Archaeological Survey Report, No. 205. Center for Archaeological Research, The University of Texas at San Antonio.

Escobedo, S.

1984 Untitled report on 1984 excavations at Mission Espada. Manuscript on file at the Center for Archaeological Research, The University of Texas at San Antonio.

Fox, A. A., and T. R. Hester

1976 Archaeological Test Excavations at Mission San Francisco de la Espada. Archaeological Survey Report, No. 22. Center for Archaeological Research, The University of Texas at San Antonio.

Fox, A. A., F. A. Bass, and T. R. Hester

1976 The Archaeology and History of Alamo Plaza. Archaeological Survey Report, No. 16. Center for Archaeological Research, The University of Texas at San Antonio.

Fox, A. A.

1981 Test Excavations at Mission San Francisco de la Espada. Archaeological Survey Report, No. 108. Center for Archaeological Research, The University of Texas at San Antonio.

Gross, K. J.

1997 Archaeological Testing of the New Plaza at Mission San Francisco de la Espada (41BX4), San Antonio, Texas. Archaeological Survey Report, No. 262. Center for Archaeological Research, The University of Texas at San Antonio.

Habig, M. A.

1968 The Alamo Chain of Missions: A History of San Antonio's Five Old Missions. Franciscan Herald, Chicago.

Hard, R. J., A. A. Fox, I. W. Cox, K. J. Gross, B. A. Meissner, G. J. Méndez, C. L. Tennis, and J. E. Zapata 1995 Excavations at Mission San José y San Miguel de Aguayo, San Antonio, Texas. Archaeological Survey Report, No. 218. Center for Archaeological Research, The University of Texas at San Antonio.

Ivey, J. E., M. B. Thurber, and S. Escobedo

1990 Of Various Magnificence. The Architectural History of the San Antonio Missions in the Colonial Period and the Nineteenth Century. Volume One. National Park Service Professional Papers No. 11, Santa Fe. Draft on file at the Center for Archaeological Research, The University of Texas at San Antonio. 
Killen, K., and D. Scurlock

1977 A Report on Preliminary Test Excavations at Mission Espada Kilns, San Antonio, Texas. Manuscript on file, Center for Archaeological Research, The University of Texas at San Antonio.

Meskill, F. K.

1992 Archaeological Testing Within the Southeast Corner of the Plaza at Mission Espada, San Antonio, Bexar County, Texas. Archaeological Survey Report, No. 208. Center for Archaeological Research, The University of Texas at San Antonio. 

